\title{
Systematic training model for teaching, development and training of instructors in inguinal hernia treatment using the Lichtenstein technique. Hernia campaign 2014 \& 2015.
}

\section{Modelo de treinamento sistematizado para o ensino, desenvolvimento e formação de instrutores no tratamento da hérnia inguinal pela técnica de Lichtenstein. Mutirão da hérnia 2014 e 2015.}

Carlos José Lazzarini-Mendes ${ }^{1}$; Adhemar Monteiro Pacheco Júnior, TCBC-SP1; Bárbara Bozzol Destro ${ }^{1}$; Caroline Tamaro ${ }^{1}$; Fábio Antonio Del Picchia de Araújo Nogueira ${ }^{1}$; David Chen²; Wolfgang Reinpold ${ }^{3}$; Vitor Bruscagin'; Sergio Roll, TCBC-SP1; Rodrigo Altenfelder Silva, TCBC-SP'1.

\begin{abstract}
A B S T R A C T
Objective: to evaluate the method of training and continuing education of 18 surgeons in 2014, and 28 surgeons in 2015, in the Holy Homes of Ribeirao Preto, Araraquara, Franca and San Carlos of São Paulo, in the performance of Lichtenstein inguinal herniorrhaphy, tutored by the Faculty of Medical Sciences of the São Paulo Holy Home and the organization HERNIA HELP - "Hernia Repair for the Underserved". Methods: the training was tutored and systematized through an active methodology of teaching and learning, aiming to offer competence, skills and attitudes, measured by a previously validated Qualification Form, qualifying leaders in trainees' improvement. Results: in 2014 the outcomes were: the difficulty of the case, direction, incision, dissection, mesh preparation, mesh cutting, mesh setting, closing, instruments, respect to tissues, flow, time and motion, and performance, all presented change in the general rating $(p=0.000002)$; there was greater confidence in the execution of the procedure in $80 \%$ of trainees, considered "very valuable" in $93.3 \%$ of the interventions. In 2015, 28 surgeons were trained by ten surgeons previously qualified in 2014. The nerve identification rate, a relevant time the Lichtenstein technique, was 95.5\% for the lliohypogastric, 98.5\% for the ilioinguinal and $89.4 \%$ for the genital branch of the genitofemoral nerve. Conclusion: the applied teaching method is possible, reproducible, reliable and valid. The joint efforts offer enormous opportunity of directed education, reaching underserved populations, revealing the great teacher-student social responsibility.
\end{abstract}

Keywords: Educational Measurement. Hernia, Inguinal. Professional Training. Surgical Procedures, Operative. Teaching.

\section{INTRODUCTION}

$T$ he concepts of Medical Education have been strong influences of society, of knowledge "per se" and of health systems. The National Curriculum Guidelines Law of the Brazilian Graduate Courses in Medicine establishes precepts in "Skills and Abilities", subclause - Continuing Education, stating that: "Providers should be able to learn continuously, both in their education and in their practice. Thus, health professionals must learn to learn and take responsibility and commitment to their education and training of future generations of professionals, but providing conditions so that there is mutual benefit among the future professionals and the staff, including stimulating and developing academic/ vocational mobility, training and cooperation through national and international networks" ${ }^{1}$.

It should be considered that the professional inserted in Public Health should include in his/her scope, beyond the technical-scientific issues, the question of social responsibility, allying with government sectors ${ }^{2}$. The certification, recertification and maintenance of skills in the medical field are widely applied and discussed in various forms and in various countries like USA, Canada, New Zealand, Britain, France, Germany, Portugal, Argentina, Chile, Colombia, Mexico and Panama. In Brazil there are already initiatives in this area ${ }^{3,4}$.

According to Youngsson ${ }^{5}$, in an article that discussed the teaching and assessment of non-technical skills, surgical excellence is a composite of skill, ability,

1 - Department of Surgery, Faculty of Medical Sciences of the Holy Home, São Paulo, SP, Brazil. 2 - Clinical Surgery, Lichtenstein Amid Hernia Clinic at UCLA, Santa Monica, CA, USA. 3 - Department of Surgery, Academic Teaching Hospital of the University of Hamburg, Wilhelmsburger Groß-Sand Hospital, Hamburg, Germany. 
behavior and attitudes with solid intellectual foundation. According to MacRae ${ }^{6}$, the need for objective assessment of technical skills can be accomplished in several ways, each with its own peculiarities and criticism; however, there is consensus that when properly applied it minimizes errors.

There were several proposals for inguinal hernia correction in the course of the surgery history, among them the Lichtenstein technique, presented in 1989 and referred to as "tension-free", replacing sutures under tension in the groin, interposing a polypropylene prosthetic mesh?

In Brazil, the use of meshes is authorized and standardized in accordance with Article 5 of the Ministry of Health's Ordinance No. 2036, of November 24, $2002^{8}$.

Despite herniorrhaphies being an option, the tension-free technique with prosthesis under local anesthesia takes an important position since the systematic review of the Cochrane Library in 2002 and the guidelines of the European Hernia Society for treating adult inguinal hernias ${ }^{9-11}$.

Based on these assumptions, we believe that the teaching of the Lichtenstein technique is important in public health, as a means of continuous and supervised medical education, provided its assessment through a systematic and institutional teaching method, offering surgeons the opportunity of acquiring skills, abilities and attitudes appropriate to the proposed task.

The aim of this study was to evaluate the systematic training through an active teaching methodology in the realization of Lichtenstein inguinal hernia repair under joint supervision of the Brotherhood of The São Paulo Holy Home of Mercy of / Faculty of Medical Sciences of The São Paulo Holy Home of Mercy (FCMSCSP) and the non-governmental organization HERNIA HELP Hernia Repair for the Underserved (HRFU), coordinated by the Abdominal Wall Group of the Department of Surgery FCMSCSP.

\section{METHODS}

Through standardized and systematic teaching, 18 surgeons from hospitals of the Brotherhood of
The São Paulo Holy Home in 2014, and 28 surgeons of the The Holy Homes of the cities of Ribeirão Preto, Araraquara, Franca and São Carlos in the State of São Paulo in 2015. They attended a lecture on the surgical treatment of inguinal hernia by the Lichtenstein technique, when they received detailed explanation of the technical aspects, intraoperative traps, tactics to avoid complications and critical analysis of postoperative complications, interactively discussing, criticizing and asking questions about the technique's step-by-step. In the 2015 Campaign, ten surgeons from the 2014 training participated as teachers. Teachers, as well as students and patients, signed the Informed Consent Form, according to the Opinion of the Ethics in Research Committee of the Brotherhood of The São Paulo Holy Home of Mercy, CAAE: 47189715.1 .0000 .5479$.

Once known the surgical tactic and technique, surgeons were summoned to the operating room for a detailed discussion of the cases to be operated, in an individualized way, with their respective tutor.

To measure skills, abilities and attitudes, the surgeon, then called student, actively participated in five procedures. In the first surgery, students helped the teacher, and from then on, performed four operations aided by the teacher, in which he/she should demonstrate knowledge, skill and ability to conduct the operative times. After each intervention where the student performed the procedure, the teacher performed the assessment by the Qualification Form ${ }^{12}$, and scored the questions assigning from 1 to 5, namely (Annex):

For analysis of the Qualification Form outcomes, we used the Student's test $t(\alpha=0.05)$.

We adjusted generalized estimating equations models with the Poisson distribution, considering the correlation between the measurements of the same student in different assessments of the same item. We presented the model results by adjusted average values and 95\% confidence intervals.

Multiple comparisons were corrected by the Bonferroni method, adopting the 0.05 significance level $(\alpha=5 \%)$. We used the SPSS software, version 18.0 (SPSS Inc. Released 2009 PASW Statistics for Windows, Version 18.0 Chicago. SPSS Inc.). 


\section{RESULTS}

We applied the Lichtenstein inguinal hernia repair technique in 74 patients, with 79 inguinal hernias, training 18 surgeons at four hospitals in a three-day period in the 2014 Campaign. There was no mortality and no reoperations. As for surgical skills, there was a significant change in the items: Incision $(p=0.001)$, dissection ( $p=0.009)$, preparation ( $p=0.02)$ mesh cutting $(p=0.01)$, mesh fixation $(p=0.0004)$ instruments handling $(p=0.004)$, respect for tissues $(p=0.03)$, time and motion $(p=0.005)$, operative flow $(p=0.01)$, closing $(p=0.004)$ and general classification ( $p=0.000002$ ) (Table 1$)$, shown by the range performance curves (Figure 1).

The questionnaire noting the outcome "Changes in Post-Training Practice" revealed "extensive changes" in 13.3\%, "moderate change" in $73.3 \%$ and "no change" in 13.3\%. As for the "Confidence level", data revealed "Same Confidence" in 20\% and "More Confidence" in implementing the procedure in $80 \%$ of students. As for the post-training questionnaire, "training value" revealed: "Something valuable" by $6.7 \%$ and "very valuable" in $93.3 \%$ of the cases.

In 2015 Campaign, 28 surgeons were trained by ten surgeons previously qualified in 2014, operating 139 patients with 141 hernias in three days. We excluded one patient from the study due to lack of anesthetic conditions.

We found no significant differences between the average scores in the four assessments regarding case difficulty, mesh preparation, closing, instruments and respect to the tissues ( $p>0.05$ for all comparisons). We observed higher means in the fourth evaluation when compared with the average of the first evaluation for the direction ( $p=0.038)$ and dissection $(p=0.013)$. The incision item had a higher average in evaluation three when compared with evaluation one $(p=0.010)$. We observed that the average scores for the outcome cut in the fourth assessment was higher than the average ratings in the first evaluation $(p<0.001)$. The average grades for mesh

\section{Scores}

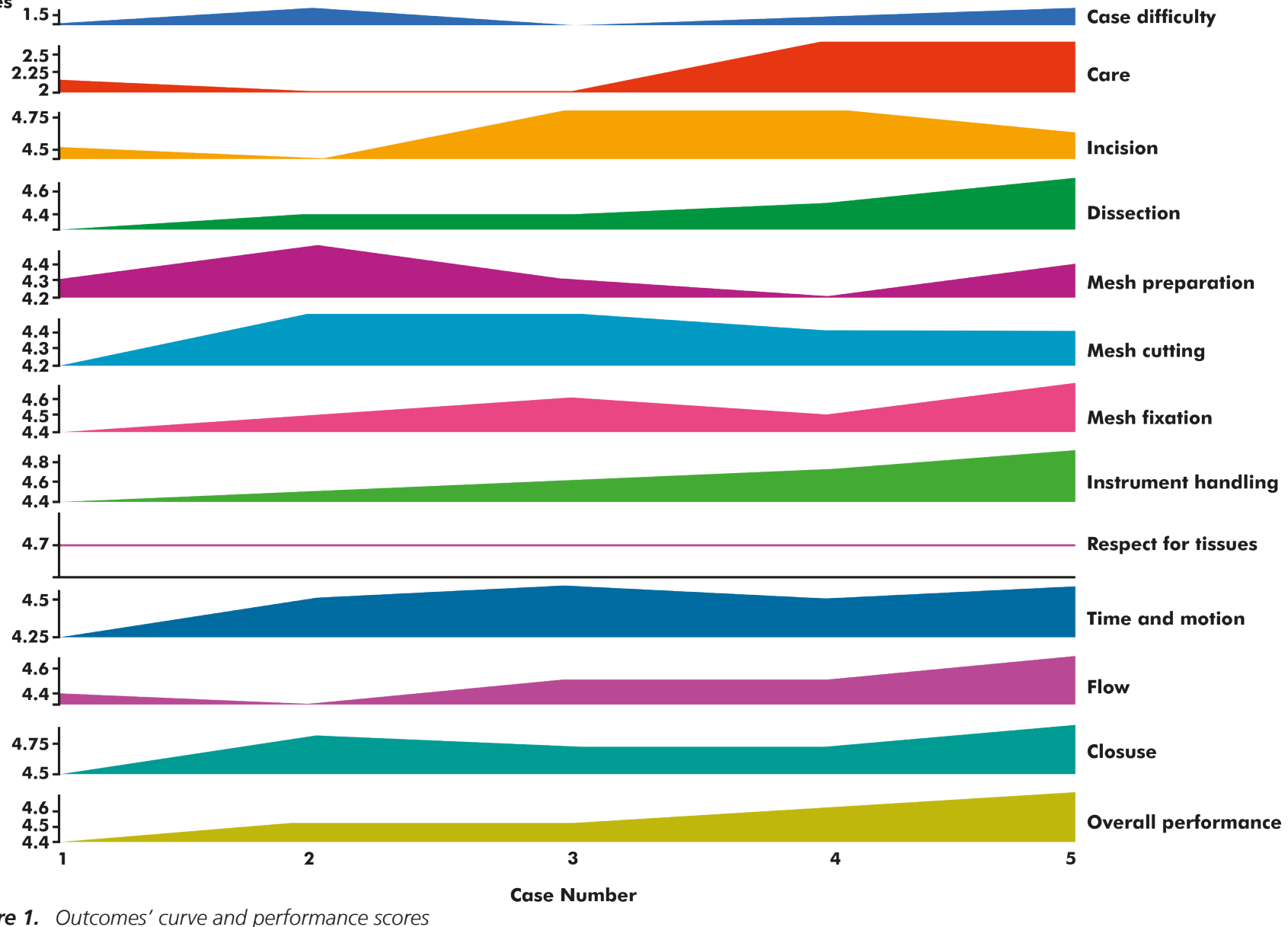

Figure 1. Outcomes' curve and performance scores 
Table 1 - Statistical analysis of outcomes.

\begin{tabular}{cccccccc}
\hline Surgical Skills & $\begin{array}{c}\text { Score } \\
1^{\text {st }} \text { case }\end{array}$ & SD $_{1}$ & SEM $_{1}$ & $\begin{array}{c}\text { Score } \\
\text { final case }\end{array}$ & SD $_{2}$ & SEM $_{2}$ & $p_{\text {-value }}{ }^{b}$ \\
\hline Incision & 4.27 & 0.67 & 0.04 & 4.88 & 0.32 & 0.025 & 0.001 \\
Direction & 4.16 & 0.71 & 0.04 & 4.72 & 0.46 & 0.03 & 0.009 \\
Preparation & 4.22 & 0.73 & 0.04 & 4.72 & 0.46 & 0.03 & 0.02 \\
Mesh cutting & 4.11 & 0.76 & 0.04 & 4.72 & 0.57 & 0.03 & 0.01 \\
Mesh fixation & 4.16 & 0.62 & 0.03 & 4.83 & 0.38 & 0.02 & 0.0004 \\
Instrument handling & 4.27 & 0.67 & 0.04 & 4.83 & 0.38 & 0.02 & 0.004 \\
Respect for tissues & 4.38 & 0.50 & 0.03 & 4.77 & 0.55 & 0.03 & 0.03 \\
Time and motion & 4.05 & 0.64 & 0.04 & 4.66 & 0.59 & 0.03 & 0.005 \\
Flow & 4.22 & 0.55 & 0.03 & 4.66 & 0.49 & 0.03 & 0.01 \\
Closing & 4.44 & 0.51 & 0.03 & 4.88 & 0.32 & 0.02 & 0.004 \\
Overall performance & 4.11 & 0.47 & 0.03 & 4.88 & 0.32 & 0.02 & 0.000002 \\
\hline
\end{tabular}

a Points for average, ${ }^{b}$ t-test, $\alpha=0.05$, SD: standard deviation; SEM: standard error of the mean.

fixation in evaluation three was greater than the first assessment ( $p=0.038$ ). For the time and motion outcome, we found a higher average score in the fourth assessment compared with the second one $(p=0.003)$. We observed that the average scores for the flow and performance outcome in the fourth evaluation were higher than the average ratings in the first $(p=0.027$ for Flow and $p=0.017$ for Performance). Table 2 shows the statistical analysis.

\section{DISCUSSION}

The teaching of surgery dates back to centuries. However, it fell to Dr. William Stewart Halsted, at Johns Hopkins Hospital in 1889, the merits of introducing a supervised and tutored education and training system for surgeons in the learning phase, featuring the creation of the Medical Residency ${ }^{13}$.

In Brazil, Decree No. 80281 of September 5, $1977^{14}$ formally regulated the medical residency as a form of post-graduate education. Over the years, the surgical specialties advanced in number and importance, so much so that there are schools of thought that believe that there will not be, in the near future, a Surgeon General, but "Surgeons of hernias and abdominal wall", for example ${ }^{13}$.

In Education, the classic Miller pyramid has been widely used for the understanding and develop- ment of knowledge construction methods, where the individual shows that he knows, knows how, shows how and does. Nevertheless, one must recognize the necessary of skills assessment in the real clinical practice, the DOES level ${ }^{15,16}$.

Among the many teaching tools, the David Ausubel Theory of Meaningful Learning, published in 1968, states that the individual can significantly learn certain content, adding new information to those which were constant in his cognitive structure, on the premise that there is willingness to learn. This justifies the use of active learning methodologies in the sense that the professional incorporates elements indispensable to clinical practice ${ }^{15,16}$.

Attentive to national and international humanitarian actions, the authors considered that the proposed task force for surgical treatment of inguinal hernia to needy populations might represent a significant contribution and enhancement of social responsibility of health professionals ${ }^{17}$.

This humanitarian action is not aimed at the study of new surgical techniques, applying treatment already established in the literature, offering the Brazilian public health system the opportunity to shorten the long queues.

The teaching method used in this study showed a clear evolution of the concept: "See One, Do One, 
Table 2 - Estimated Measures of ratings' scores and 95\% confidence intervals.

\begin{tabular}{|c|c|c|}
\hline \multirow{3}{*}{ Notes } & \multicolumn{2}{|c|}{ Reviews of procedures } \\
\hline & 2 & 3 \\
\hline & Mean $(\mathrm{Cl})$ & Mean (CI) \\
\hline \multirow[t]{2}{*}{ Difficulty of the case } & $1.2[1.1 ; 1.4]$ & $1.4[1.2 ; 1.7]$ \\
\hline & $1 \times 2: p=1.000$ & $2 \times 3: p=1.000$ \\
\hline \multirow[t]{2}{*}{ Multiple comparisons } & $1 \times 3: p=0.583$ & $2 \times 4: p=1.000$ \\
\hline & $1 \times 4: p=1.000$ & $3 \times 4: p=0.502$ \\
\hline \multirow[t]{2}{*}{ Direction } & $1.9[1.6 ; 2.2] \quad 2.1[1.8 ; 2.3]$ & $2.2[2.41 .9 ;] \quad 2.4[2.1 ; 2.8]$ \\
\hline & $1 \times 2: p=1.000$ & $2 \times 3: p=1.000$ \\
\hline \multirow{2}{*}{ Multiple comparisons } & $1 \times 3: p=0.757$ & $2 \times 4: p=0.186$ \\
\hline & $1 \times 4: p=0.038$ & $3 \times 4: p=0.379$ \\
\hline \multirow[t]{2}{*}{ Incision } & $4.1[3.8 ; 4.3] \quad 4.1[3.8 ; 4.4]$ & $4.6[4.84 .3 ;] \quad 4.5[4.2 ; 4.9]$ \\
\hline & $1 \times 2: p=1.000$ & $2 \times 3: p=0.067$ \\
\hline Multiple comparisons & $1 \times 3: p=0.010$ & $2 \times 4: p=0.149$ \\
\hline & $1 \times 4: p=0.093$ & $3 \times 4: p=1.000$ \\
\hline Dissection & $4.1[3.8 ; 4.3] \quad 4.1[3.8 ; 4.3]$ & $4.3[3.9 ; 4.6] \quad 4.6[4.94 .3 ;]$ \\
\hline & $1 \times 2: p=1.000$ & $2 \times 3: p=1.000$ \\
\hline Multiple comparisons & $1 \times 3: p=1.000$ & $2 \times 4: p=0.069$ \\
\hline & $1 \times 4: p=0.013$ & $3 \times 4: p=0.538$ \\
\hline Mesh preparation & $4.1[3.8 ; 4.3] \quad 4.1[3.8 ; 4.4]$ & $4.2[3.9 ; 4.5] \quad 4.5[4.1 ; 4.8]$ \\
\hline & $1 \times 2: p=1.000$ & $2 \times 3: p=1.000$ \\
\hline Multiple comparisons & $1 \times 3: p=1.000$ & $2 \times 4: p=0.602$ \\
\hline & $1 \times 4: p=0.254$ & $3 \times 4: p=0.613$ \\
\hline Mesh Cutting & $3.9[3.6 ; 4.1] \quad 4.1[3.9 ; 4.4]$ & $4.4[4.1 ; 4.6] \quad 4.6[4.4 ; 4.8]$ \\
\hline & $1 \times 2: p=0.429$ & $2 \times 3: p=0.541$ \\
\hline Multiple comparisons & $1 \times 3: p=0.026$ & $2 \times 4: p=0.004$ \\
\hline & $1 \times 4: p<0.001$ & $3 \times 4: p=0.377$ \\
\hline Mesh Fixation & $4.2[3.9 ; 4.4] \quad 4.1[3.8 ; 4.4]$ & $4.6[4.4 ; 4.8] \quad 4.5[4.2 ; 4.8]$ \\
\hline & $1 \times 2: p=1.000$ & $2 \times 3: p=0.003$ \\
\hline Multiple comparisons & $1 \times 3: p=0.038$ & $2 \times 4: p=0.108$ \\
\hline & $1 \times 4: p=0.408$ & $3 \times 4: p=1.000$ \\
\hline Closing & 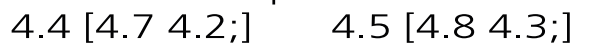 & $4.7[4.5 ; 4.9] \quad 4.8[4.6 ; 5.0]$ \\
\hline & $1 \times 2: p=1.000$ & $2 \times 3: p=0.955$ \\
\hline Multiple comparisons & $1 \times 3: p=0.248$ & $2 \times 4: p=0.337$ \\
\hline & $1 \times 4: p=0.197$ & $3 \times 4: p=1.000$ \\
\hline Instruments Handling & $4.4[4.1 ; 4.6] \quad 4.2[3.8 ; 4.5]$ & $4.5\left[\begin{array}{lll}4.7 & 4.3 ;] & 4.5 \\
4 & 4.8 & 4.3 ;]\end{array}\right.$ \\
\hline & $1 \times 2: p=1.000$ & $2 \times 3: p=0.389$ \\
\hline Multiple comparisons & $1 \times 3: p=1.000$ & $2 \times 4: p=0.202$ \\
\hline & $1 \times 4: p=1.000$ & $3 \times 4: p=1.000$ \\
\hline Respect for tissues & $4.4[4.2 ; 4.6] \quad 4.2[3.9 ; 4.5]$ & $4.4[4.74 .2 ;] \quad 4.7[4.4 ; 4.9]$ \\
\hline & $1 \times 2: p=1.000$ & $2 \times 3: p=0.996$ \\
\hline Multiple comparisons & $1 \times 3: p=1.000$ & $2 \times 4: p=0.081$ \\
\hline & $1 \times 4: p=0.905$ & $3 \times 4: p=0.947$ \\
\hline Time and Motion & $4.1[3.8 ; 4.4] \quad 3.9[3.5 ; 4.3]$ & $4.3[3.9 ; 4.6] \quad 4.6[4.94 .3 ;]$ \\
\hline & $1 \times 2: p=1.000$ & $2 \times 3: p=0.163$ \\
\hline Multiple comparisons & $1 \times 3: p=1.000$ & $2 \times 4: p=0.003$ \\
\hline & $1 \times 4: p=0.056$ & $3 \times 4: p=0.509$ \\
\hline Flow & $4.1[3.8 ; 4.4] \quad 4.0[3.7 ; 4.4]$ & $4.3[4.0 ; 4.6] \quad 4.6[4.4 ; 4.9]$ \\
\hline & $1 \times 2: p=1.000$ & $2 \times 3: p=0.425$ \\
\hline Multiple comparisons & $1 \times 3: p=1.000$ & $2 \times 4: p=0.020$ \\
\hline & $1 \times 4: p=0.027$ & $3 \times 4: p=0.412$ \\
\hline Overall Performance & $4.1[3.9 ; 4.3] \quad 4.0[3.7 ; 4.3]$ & $4.4[4.1 ; 4.7] \quad 4.6[4.4 ; 4.9]$ \\
\hline & $1 \times 2: p=1.000$ & $2 \times 3: p=0.123$ \\
\hline Multiple comparisons & $1 \times 3: p=0.495$ & $2 \times 4: p=0.005$ \\
\hline & $1 \times 4: p=0.017$ & $3 \times 4: p=0.839$ \\
\hline
\end{tabular}

(CI): Confidence Interval. 
Teach One", recorded in the Post-training practice questionnaire, to the extent that the students demonstrate the evolution of their skills ${ }^{18,19}$.

Through the results of studying the teaching method in question, we clearly observed that the proximity between student and teacher, focused on the pursuit of perfection, attended principles of learning in which the teacher acted as supervisor, advisor and facilitator, of reflective character, as a sponsor and friend ${ }^{20,21}$. These aspects were highlighted in the 2014 Confidence Level and Training Value questionnaires.

The analysis of the performance curves for the outcomes in skills acquisition was evidenced by the item Overall Performance $(p=0.000002)$ in the 2014 Campaign, demonstrating that the method was effective.

The study showed a significant and relevant difference on outcomes during the four herniorrhaphies that unequivocally demonstrated an obvious continuing medical education character in the 2015 Campaign, when the 2014 students, then teachers, implemented and transferred abilities and attitudes in promoting skills. The outcomes Direction, Incision, Dissection Mesh Cutting, Mesh Fixation, Flow and Overall Performance composed the success of this training scenario.

\section{CONCLUSION}

The joint and quality effort between national and international institutions is possible, strengthening human relationships that go beyond technology. The training of surgeons was essential for technical standardization of surgical tactics, allowing them to become multipliers of education and training of their peers.

Skills, competencies and attitudes were fully achieved with this type of education. The Campaigns demonstrated citizenship and social responsibility outside the university environment. The teaching method allowed us to conclude that there is full conditions of reproducibility of this continuing education method.

\title{
R E S U M O
}

\begin{abstract}
Objetivo: avaliar resultados do método de treinamento e educação continuada de 18 cirurgiões, em 2014, e 28 cirurgiões, em 2015 , nas Santas Casas de Ribeirão Preto, Araraquara, Franca e São Carlos do Estado de São Paulo, na realização da Herniorrafia Inguinal à Lichtenstein, tutorados pela Faculdade de Ciências Médicas da Santa Casa de São Paulo e pela organização HERNIA HELP - "Hernia Repair for the Underserved". Métodos: treinamento tutorado e sistematizado, através de metodologia ativa de ensino e aprendizagem, visando a oferecer competência, habilidade e atitudes, auferidas por um Formulário de Qualificação previamente validado, qualificando líderes no aperfeiçoamento de treinandos. Resultados: em 2014, os desfechos foram: dificuldade do caso, direção, incisão, dissecção, preparo da tela, corte da tela, fixação da tela, fechamento, instrumentos, respeito aos tecidos, fluxo, tempo e movimento e desempenho, apresentaram mudança na Classificação Geral ( $p=0,000002)$; houve maior confiança na execução do procedimento em $80 \%$ dos treinandos, sendo considerado "Muito Valioso" em 93,3\% das participações. Em 2015, os 28 cirurgiões foram treinados por dez cirurgiões previamente qualificados em 2014. A taxa de identificação dos nervos, tempo relevante da técnica de Lichtenstein, foi 95,5 \% para o ílio-hipogástrico, 98,5\% para o ilioinguinal e 89,4\% para o ramo genital do nervo genitofemoral. Conclusão: o método de ensino aplicado é possível, reprodutível, confiável e válido. Os mutirões oferecem a enorme oportunidade do ensino, dirigido, atingindo populações carentes, revelando a grande responsabilidade social docente-discente.
\end{abstract}

Descritores: Avaliação Educacional. Capacitação Profissional. Ensino. Hérnia Inguinal. Procedimentos Cirúrgicos Operatórios

\section{REFERENCES}

1. Diretrizes Curriculares Nacionais do Curso de Graduação em Medicina [Internet]. 2003. pp. 1-5. [cited 2015 Oct 9]. Available from: http://portal.mec.gov.br/ cne/arquivos/pdf/Med.pdf.

2. Xavier AS, Koifman L. Educação superior no Brasil e a formação dos profissionais de saúde com ênfase no envelhecimento. Interface (Botucatu). 2011;15(39):973-84.
3. Siqueira BP. Certificação e manutenção de competência na área médica: breve revisão. Rev Med Minas Gerais. 2003;13(2):132-6.

4. Castelo HB, Penedo J. As sociedades científicas e a formação pós-graduada. Rev port cir. 2010;14:91-3.

5. Youngson GG. Teaching and assessing non-technical skills. Surgeon. 2011;9(Suppl 1):S35-7.

6. MacRae HM. Objective assessment of technical skill. Surgeon. 2011;9 Suppl 1:S23-5.

7. Lichtesntein IL, Shulman AG, Amid PK, Montl- 
lor MM. The tension-free hernioplasty. Am J Surg. 1989;157(2):188-93.

8. Ministério da Saúde - Departamento Nacional de Auditoria do SUS - Coordenação de Sistemas de Informação do Sistema Único de Saúde. Artigo 5ㄴ, da Portaria no 2036, de 24 de novembro de 2002 [Internet]. Códigos: 93481209; 93481217; 93481225 e 93481390. Legislação Federal. pp. 1-13. [cited 2015 Oct 9]. Available from: http://www.sbccv.org.br/medica2-old/downloads/Portaria\%20n. \% C2\%BA\%20 2036.GM\%20TABELA\%20REF. \% 20\% C3\%93RTESES. \% 20PR \% C 3\% 93TESES \% 20E \% 20MATERIAS\%20ESPECIAIS\%20DO\%20SIH-SUS.pdf.

9. Amid PK, Shulman AG, Lichtesntein IL. Local anesthesia for inguinal hernia repair step-by-step procedure. Ann Surg. 1994;220(6)735-7.

10. Scott NW, McCormack K, Graham P, Go PM, Ross SJ, Grant AM. Open mesh versus non-mesh for femoral and inguinal hernia. Cochrane Database Syst Rev. 2002;(4):CD002197.

11. Simons MP, Aufenacker T, Bay-Nielsen M, Bouillot JL, Campanelli G, Conze J, et al. European Hernia Society guidelines on the treatment of inguinal hernia in adult patients. Hernia. 2009;13(4):343-403.

12. Larson $\mathrm{JL}$, Williams RG, Ketchum J, Boehler ML, Dunnington GL. Feasibility, reliability and validity of an operative performance rating system for evaluating surgery residents. Surgery. 2005;138(4):640-7; discussion 647-9.

13. Cameron JL. Willian Stewart Halsted. Our surgical heritage. Ann Surg. 1997;225(5):445-58.

14. Poder Executivo. Decreto no 80.281 , de 5 de setembro de 1977. Regulamenta a Residência Médica, cria a Comissão Nacional de Residência Médica e dá outras providências. Diário Oficial da União - Seção 1 - 6/9/1977, pp. 11787.

15. Miller GE. The assessment of clinical skills/competence/performance. Acad Med. 1990;65(9 Suppl):S63-7.

16. Shalhoub J, Vesey AT, Fitzgerald JE. What evidence is there for the use of workplace-based assessment in surgical training? J Surg Educ. 2014;71(6):906-15.

17. Losey-Flores K, Benzar R, Chan JM, Go S, Montoure A, Phillips KK, et al. Free hernia surgery for the underserved is possible in the United States. Hernia. 2014;18(2):305-10.

18. Dale E. Audio-visual methods in teaching. New York: Dryden Press; 1946.

19. Kotsis SV, Chung KC. Application of the "see one, do one, teach one" concept in surgical training. Plast Reconstr Surg. 2013;131(5):1194-201.

20. Macafee DA. Is there a role for mentoring in surgical specialty training? Med Teach. 2008;30(2):e55-9.

21. Sinclair P, Fitzgerald JE, McDermott FD, Derbyshire L, Shalhoub J; ASiT Mentoring Collaboration, et al. Mentoring during surgical training: consensus recommendations for mentoring programmes from the Association of Surgeons in Training. Int J Surg. 2014;12 Suppl 3:S5-8.

Received in: 16/06/2016

Accepted for publication: 04/09/2016

Conflict of interest: none.

Source of funding: none.

\section{Mailing address:}

José Carlos Lazzarini-Mendes

E-mail: cjlmendes@gmail.com; cropac03@terra.com.br 


\section{Annex}

\section{Form 1 - Lichtenstein Inguinal Hernia Repair - Rating Form}

Evaluator:

Student:

Program:

Case Number:

Please rate this trainee's performance during this operative procedure. The caption above each item provides descriptive anchors for 3 of the 5 points on the rating scale. "NIA" (Not applicable) should only be selected when the trainee did not perform that part of the procedure.

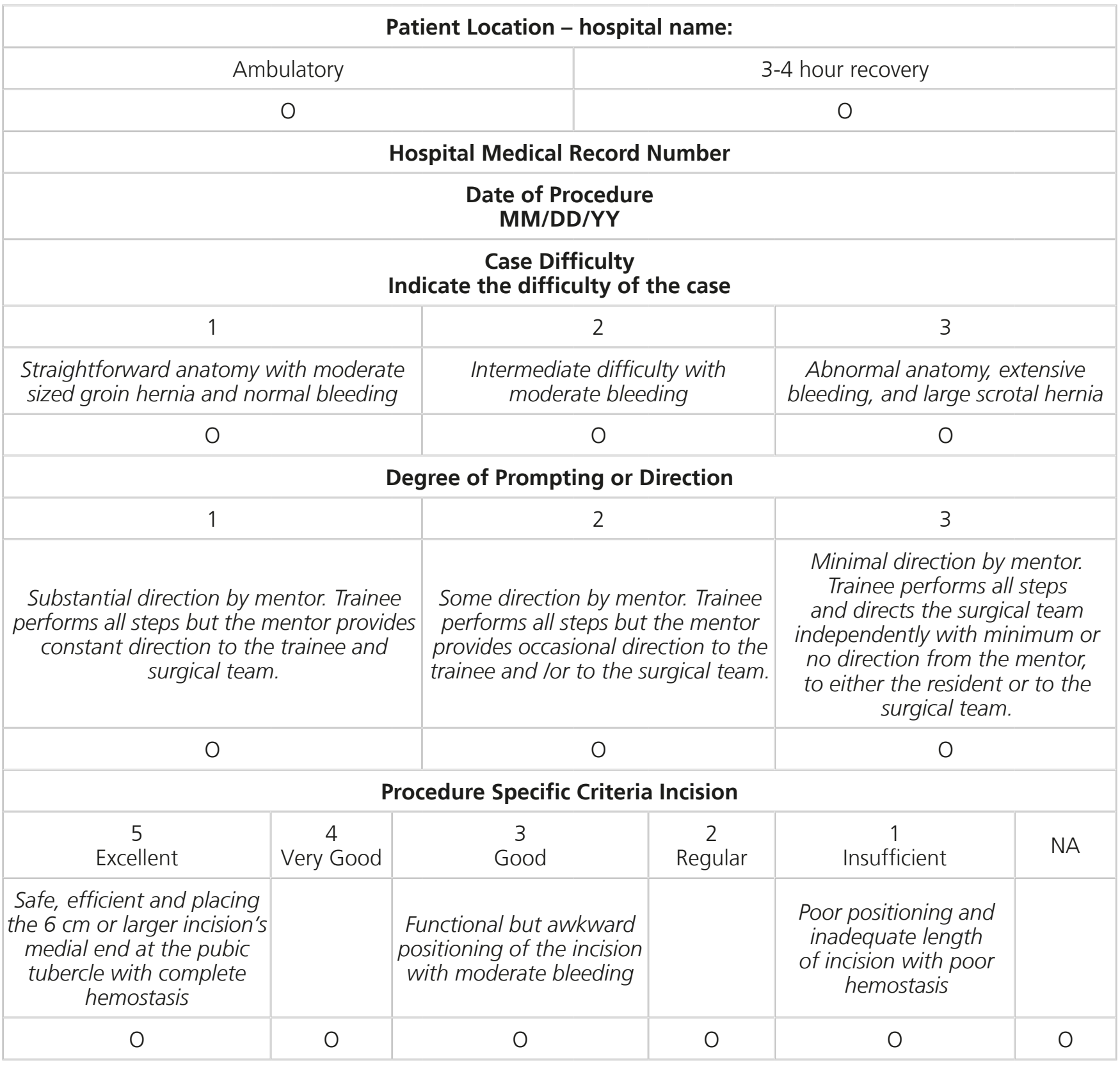




\begin{tabular}{|c|c|c|c|c|c|}
\hline \multicolumn{6}{|c|}{ Dissection of tissue and hernia sac } \\
\hline $\begin{array}{c}5 \\
\text { Excellent }\end{array}$ & Very Good & $\begin{array}{c}3 \\
\text { Good }\end{array}$ & $\stackrel{2}{2}$ & $\begin{array}{c}1 \\
\text { Insufficient }\end{array}$ & NA \\
\hline $\begin{array}{c}\text { Optimizes visualization, } \\
\text { and sees ilioinguinal, } \\
\text { iliohypogastric and genital } \\
\text { branch of genitofemoral } \\
\text { nerve, vas deferens and } \\
\text { cord vessels with careful } \\
\text { sac dissection and complete } \\
\text { inversión. }\end{array}$ & & $\begin{array}{c}\text { Adequate visualization, } \\
\text { and sees ilioinguinal, } \\
\text { iliohypogastric and genital } \\
\text { branch of genitofemoral } \\
\text { nerve, vas deferens and } \\
\text { cord vessels with difficulty. } \\
\text { Sac dissection is complete } \\
\text { but with moderate } \\
\text { bleeding and probable } \\
\text { satisfactory inversion or } \\
\text { ligation. }\end{array}$ & & $\begin{array}{l}\text { Poor visualization and } \\
\text { sees only the ilioinguinal } \\
\text { nerve. Sac dissection } \\
\text { is incomplete with } \\
\text { poor hemostasis and } \\
\text { unsatisfactory sac } \\
\text { inversion or ligation. }\end{array}$ & \\
\hline O & O & O & O & O & $\mathrm{O}$ \\
\hline \multicolumn{6}{|c|}{ Preparation for Mesh Placement } \\
\hline $\begin{array}{c}5 \\
\text { Excellent }\end{array}$ & $\begin{array}{c}4 \\
\text { Very Good }\end{array}$ & $\begin{array}{c}3 \\
\text { Good }\end{array}$ & $\begin{array}{c}2 \\
\text { Regular }\end{array}$ & $\begin{array}{c}1 \\
\text { Insufficient }\end{array}$ & NA \\
\hline $\begin{array}{c}\text { Expedient with rectus } \\
\text { sheath completely defined, } \\
\text { course of iliohypogastric } \\
\text { nerve well seen and room } \\
\text { for mesh placement. }\end{array}$ & & $\begin{array}{c}\text { Adequate with rectus } \\
\text { sheath and iliohypogastric } \\
\text { nerve seen but more } \\
\text { cephalad, caudad and } \\
\text { medial dissection needed. }\end{array}$ & & $\begin{array}{c}\text { Rectus sheath and } \\
\text { iliohypogastric nerves } \\
\text { not identified and more } \\
\text { dissection required in all } \\
\text { directions. }\end{array}$ & \\
\hline $\mathrm{O}$ & O & $\mathrm{O}$ & O & O & $\mathrm{O}$ \\
\hline \multicolumn{6}{|c|}{ Mesh Cutting } \\
\hline $\begin{array}{c}5 \\
\text { Excellent }\end{array}$ & Very Good & $\stackrel{3}{\text { Good }}$ & $\begin{array}{c}2 \\
\text { Regular }\end{array}$ & $\begin{array}{c}1 \\
\text { Insufficient }\end{array}$ & NA \\
\hline $\begin{array}{l}\text { Expedient with rectus } \\
\text { sheath completely defined, } \\
\text { course of iliohypogastric } \\
\text { nerve well seen and room } \\
\text { for mesh placement. }\end{array}$ & & $\begin{array}{c}\text { Adequate with rectus } \\
\text { sheath and iliohypogastric } \\
\text { nerve seen but more } \\
\text { cephalad, caudad and } \\
\text { medial dissection needed. }\end{array}$ & & $\begin{array}{c}\text { Rectus sheath and } \\
\text { iliohypogastric nerves } \\
\text { not identified and more } \\
\text { dissection required in all } \\
\text { directions. }\end{array}$ & \\
\hline O & O & $\mathrm{O}$ & O & O & $\mathrm{O}$ \\
\hline \multicolumn{6}{|c|}{ Mesh Fixation } \\
\hline $\begin{array}{c}5 \\
\text { Excellent }\end{array}$ & Very Good & $\stackrel{3}{\text { Good }}$ & $\begin{array}{c}2 \\
\text { Regular }\end{array}$ & $\begin{array}{c}1 \\
\text { Insufficient }\end{array}$ & NA \\
\hline $\begin{array}{l}\text { Accurate careful and } \\
\text { correct suture placement } \\
\text { in rectus sheath inguinal } \\
\text { ligament and internal } \\
\text { oblique aponeurosis with } \\
\text { satisfactory mesh buckle, } \\
2 \mathrm{~cm} \text { medial overlap } \\
\text { of pubic tubercle and } \\
\text { satisfactory sized mesh } \\
\text { spermatic cord opening. }\end{array}$ & & $\begin{array}{c}\text { Adequate fixation } \\
\text { but awkward suture } \\
\text { placement with no } \\
\text { more than two sutures } \\
\text { slightly misplaced but still } \\
\text { with mesh buckle, and } \\
\text { satisfactory spermatic } \\
\text { cord opening and medial } \\
\text { mesh overlap. }\end{array}$ & & $\begin{array}{l}\text { Awkward fixation with } \\
\text { sutures not including } \\
\text { rectus sheath or internal } \\
\text { oblique aponeurosis, } \\
\text { or too large or too } \\
\text { small mesh opening for } \\
\text { spermatic cord, or mesh } \\
\text { too lateral in relation to } \\
\text { pubic tubercle. }\end{array}$ & \\
\hline
\end{tabular}




\begin{tabular}{|c|c|c|c|c|c|}
\hline \multicolumn{6}{|c|}{ Closure } \\
\hline $\begin{array}{c}5 \\
\text { Excellent }\end{array}$ & $\begin{array}{l}4 \\
\text { Very Good }\end{array}$ & Good & $\begin{array}{c}2 \\
\text { Regular }\end{array}$ & $\begin{array}{c}1 \\
\text { Insufficient }\end{array}$ & NA \\
\hline $\begin{array}{l}\text { Accurate external } \\
\text { oblique aponeurosis and } \\
\text { subcutaneous closure with } \\
\text { complete hemostasis and } \\
\text { good skin apposition. }\end{array}$ & & $\begin{array}{c}\text { External oblique and } \\
\text { subcutaneous tissue } \\
\text { closure with acceptable } \\
\text { hemostasis and } \\
\text { satisfactory skin closure. }\end{array}$ & & $\begin{array}{l}\text { Forgot to close one } \\
\text { layer or inadequate } \\
\text { hemostasis or poor } \\
\text { cosmetic closure of skin. }\end{array}$ & \\
\hline 0 & $\mathrm{O}$ & $\mathrm{O}$ & $\mathrm{O}$ & $\mathrm{O}$ & $\mathrm{O}$ \\
\hline \multicolumn{6}{|c|}{ General Criteria Instrument Handling } \\
\hline \multirow[t]{2}{*}{$\begin{array}{c}5 \\
\text { Excellent }\end{array}$} & $\begin{array}{c}4 \\
\text { Very Good }\end{array}$ & $\begin{array}{c}3 \\
\text { Good }\end{array}$ & $\begin{array}{c}2 \\
\text { Regular }\end{array}$ & $\begin{array}{c}1 \\
\text { Insufficient }\end{array}$ & NA \\
\hline & & $\begin{array}{l}\text { Moderately awkward } \\
\text { use of instruments, } \\
\text { occasionally used } \\
\text { excessive force, or did not } \\
\text { always have complete } \\
\text { visualization. }\end{array}$ & & $\begin{array}{l}\text { Dangerous use of } \\
\text { instruments with } \\
\text { excessive force or } \\
\text { accepted inadequate } \\
\text { visualization at } \\
\text { important parts of } \\
\text { procedure. }\end{array}$ & \\
\hline $\mathrm{O}$ & $\mathrm{O}$ & O & O & 0 & $\mathrm{O}$ \\
\hline \multicolumn{6}{|c|}{ Respect for Tissue } \\
\hline \multirow[t]{2}{*}{$\begin{array}{c}5 \\
\text { Excellent }\end{array}$} & $\begin{array}{c}4 \\
\text { Very Good }\end{array}$ & $\begin{array}{l}3 \\
\text { Good }\end{array}$ & $\begin{array}{c}2 \\
\text { Regular }\end{array}$ & $\begin{array}{c}1 \\
\text { Insufficient }\end{array}$ & NA \\
\hline & & $\begin{array}{l}\text { Moderately awkward } \\
\text { use of instruments, } \\
\text { occasionally used } \\
\text { excessive force, or did not } \\
\text { always have complete } \\
\text { visualization. }\end{array}$ & & $\begin{array}{l}\text { Dangerous use of } \\
\text { instruments with } \\
\text { excessive force or } \\
\text { accepted inadequate } \\
\text { visualization at } \\
\text { important parts of } \\
\text { procedure. }\end{array}$ & \\
\hline $\mathrm{O}$ & O & O & O & $\mathrm{O}$ & $\mathrm{O}$ \\
\hline \multicolumn{6}{|c|}{ Time and Motion } \\
\hline $\begin{array}{c}5 \\
\text { Excellent }\end{array}$ & $\begin{array}{c}4 \\
\text { Very Good }\end{array}$ & $\begin{array}{l}3 \\
\text { Good }\end{array}$ & $\begin{array}{c}2 \\
\text { Regular }\end{array}$ & $\begin{array}{c}1 \\
\text { Insufficient }\end{array}$ & NA \\
\hline $\begin{array}{l}\text { Clear economy of motion, } \\
\text { and maximum efficiency. }\end{array}$ & & $\begin{array}{c}\text { Efficient time \& motion, } \\
\text { some unnecessary } \\
\text { movement. }\end{array}$ & & $\begin{array}{l}\text { Many unnecessary } \\
\text { movements. }\end{array}$ & \\
\hline $\mathrm{O}$ & $\mathrm{O}$ & $\mathrm{O}$ & O & O & $\mathrm{O}$ \\
\hline \multicolumn{6}{|c|}{ Operation Flow } \\
\hline $\begin{array}{c}5 \\
\text { Excellent }\end{array}$ & $\begin{array}{c}4 \\
\text { Very Good }\end{array}$ & $\begin{array}{l}3 \\
\text { Good }\end{array}$ & $\begin{array}{c}2 \\
\text { Regular }\end{array}$ & $\begin{array}{c}1 \\
\text { Insufficient } \\
\end{array}$ & NA \\
\hline $\begin{array}{l}\text { Obviously planned } \\
\text { course of operation and } \\
\text { anticipation of next steps. }\end{array}$ & & $\begin{array}{c}\text { Some forward planning, } \\
\text { reasonable procedure } \\
\text { progression }\end{array}$ & & $\begin{array}{c}\text { Frequent lack of forward } \\
\text { progression; frequently } \\
\text { stopped operating and } \\
\text { seemed unsure of next } \\
\text { step. }\end{array}$ & \\
\hline $\mathrm{O}$ & $\mathrm{O}$ & $\mathrm{O}$ & O & $\mathrm{O}$ & O \\
\hline \multicolumn{6}{|c|}{ Overall Performance } \\
\hline $\begin{array}{c}5 \\
\text { Excellent }\end{array}$ & $\begin{array}{c}4 \\
\text { Very Good }\end{array}$ & $\begin{array}{c}3 \\
\text { Good }\end{array}$ & $\begin{array}{c}2 \\
\text { Regular }\end{array}$ & $\begin{array}{c}1 \\
\text { Insufficient }\end{array}$ & NA \\
\hline $\mathrm{O}$ & 0 & 0 & $\mathrm{O}$ & O & O \\
\hline \multicolumn{6}{|c|}{ Please indicate the weaknesses in this trainee's performance: } \\
\hline & ase indicat & e the strengths in this $t$ & nee's per & rmance: & \\
\hline
\end{tabular}

